\begin{tabular}{|c|c|c|}
\hline PORT SAID ENGINEERING RESEARCH JOURNAL \\
Port Said University - Faculty of Engineering \\
Volume 17 No. 2 September 2013 pp: 156-171
\end{tabular}

\title{
Stability of Steel Decks in Cable Stayed Bridges Having Delta Framing Towers
}

\author{
Nahla Kamal Hassan ${ }^{1}$, Hisham Ahmed El-Arabaty ${ }^{1}$ and Mohamed Elsaeed Elsayed Badawi ${ }^{2}$
}

\begin{abstract}
Steel decks in cable stayed Bridges with Delta Framing Towers are considered one of the most important types in cable stayed bridge category (truss girders or box steel girders). In order to evaluate the potential of decreasing horizontal drift in super-structure. Four suggested bracing systems were investigated in this paper geometry of 'Tatara Bridge' deck and its steel towers will be used. The "Tatara Bridge" is one of the world's longest steel-concrete hybrid cable stayed bridge. The side spans consist of steel and pre-stressed concrete precast concrete (PC) girders about $50 \mathrm{~m}$ from anchored spans.
\end{abstract}

KEYWORDS: stability of steel deck, cable-stayed bridges, delta framing towers, truss girders, box steel girders, super-structure, bracing systems, steel concrete hybrid cable stayed bridge and steel towers.

\section{INTRODUCTION}

The horizontal sway problem in steel decks will be explained which happened due to wind and earth quack loads at three stages of erection at steel decks have one plane of motion or two level of motion and a lot of types of bracing systems will be applied on both types of decks and present all results in tables and charts.

The Structure system for superstructure plays an important part to determine the main stiffness for the overall bridge. Two different superstructure systems (one plan and two plans) of motion will be discussed and several bracing systems will be used to investigate the optimum stability of the superstructure.

Stability of steel decks play an important part to determine the overall stability for cable stayed bridges and its bracing system is very important to decrease horizontal drift in decks.

Yabuno Masashi et al., 2008 [1] present the design of all structure elements of Tatara Bridge by using finite elements models and present all erection steps for structure elements of the bridge. The "Tatara Bridge" is the world's longest steel-concrete hybrid cable stayed bridge. It measures $1480 \mathrm{~m}$ in total length and $890 \mathrm{~m}$ in the center span.

Satouy Yoshiyuki et al., 2008 [2] present the erection of tatara bridge; the construction works for bridge began in April 1995. During the 3-month period starting in March 1996, each upper member of the main tower was installed using a climbing crane in 18 levels and the last block of the main tower was erected at the end of June 1996 (226 m high above the sea level).

M.S. Troitsky, D.SC. 1988 [3] present number of techniques can be used for the analysis of cable-stayed bridge. Examples include the use of a scaled-down model for testing, and the use of analytical model which

\footnotetext{
${ }^{T} \overline{D e p a r t m e n t}$ of Civil Engineering, Faculty of Engineering, Ain Shams University, Egypt.

${ }^{2}$ Civil Engineer
}

stayed bridge when subjected to static and dynamic conditions of loading. For small models, certain parameters should be defined and idealized, such as the restraints at the joints, the stiffness or flexibility of each member, and connections between the cables, stiffening girders and towers.

Noguchi et al., 2003; Sato et al., 2003; and Petrangeli et al., 2000 [4] reported that Nagis a Bridge was the first challenge as a compound bridge of cable-stayed prestressed concrete bridge and steel suspension bridge. Therefore there were many problems to deal with during design, material selection, and execution. Nagisa Bridge, however, was completed in December 2002. And the bridge was opened for pedestrians in July 2003.

George Moir et al, 2010 [5] reported that description for design and erection for The Phu My Bridge spans the Saigon River between Districts 7 and 2 of Ho Chi Minh City (HCMC).

Morgenthal et al., 2011 [6] described the fabrication and erection procedures for towers and the main span superstructures. The results supported that extensive wind tunnel testing as well as numerical analyses were performed to ascertain the effects of typhoon wind loads on the structure. The structural deformations predicted by the erection analysis were incorporated into a comprehensive geometric control procedure.

In this paper the deck for bridge will be enhanced, which changed from steel box section to main two trusses as main girders with cross trusses as cross beams and stringers at longitudinal direction.

Four bracing types will be used at new deck to decrease horizontal drift witch happened due to wind and earth quack forces.

Two cases from steel decks will be studded in this paper:-

- Case (I) has one level of motion

- Case (II) has two level of motion 


\section{DESCRIPTION OF THE STUDIED BRIDGE "TATARA BRIDGE"}

The "Tatara Bridge" is the one of world's longest cable stayed bridges, whose $890 \mathrm{~m}$ center span is longer than that of the "Normandy Bridge" in France by $34 \mathrm{~m}$.

Fig. 1 shows the general arrangement of the "Tatara Bridge," while the main tower is shown in Fig. 2. The section distribution is shown in Fig. 3. The main tower is $220 \mathrm{~m}$ high and designed as an inverted $\mathrm{Y}$ shape (Delta). It has a cross-shaped section with corners cut for higher wind stability and better landscaping.
The main girder section consists of three spans, 270 $\mathrm{m}, 890 \mathrm{~m}$, and $320 \mathrm{~m}$, and measures $1480 \mathrm{~m}$ in total length. Both side spans is shorter than the center span, precast concrete (PC) girders are installed at each end of both side span sections as counterweight girders to resist negative reaction. This cable stayed bridge, uses a steel and precast concrete (PC) connection girder. The bridge has a total width of $30.6 \mathrm{~m}$, including a road for motorized bicycles and pedestrians (hereafter called sidewalk) and a girder height of $2.7 \mathrm{~m}$. Cables installed in 21 levels were two-plane multi-fan cables (maximum cable length: about $460 \mathrm{~m}$ ).



Fig. 1: General arrangement (unit: mm)

\section{MATERIAL}

\subsection{Main Tower (Steel Products)}

Specifications of extra thick steel plates (for floor plates) Four floor steel plates were welded together and surfaced after annealing. The size of the plate was 13.8 * $10.3 \mathrm{~m}$. The design thickness of the plate was 200 $\mathrm{mm}$, and a 235-mm thick plate was purchased in consideration of tolerances for plate thickness, surface smoothness, deformation in welded corners, and a margin for surfacing. Defects that occurred during the rolling of the steel plates were checked based on the regulations ultrasonic testing of steel plates for pressure vessels. With regard to the (Japanese standard specifications) JIC inspection classification, an Ashaped configuration was used.

Countermeasures against samellar tearing tensile force is generated at the joints of the horizontal members of tower walls and the flanges of horizontal members where wind tanks are installed by weld ing in the direction of the thickness of a plate. Steel products used for these parts were strictly managed for their sulfur content as materials that should be managed for their sulfur content in order to prevent lamellar tearing. In addition, the soundness of steel products were confirmed where joints were welded by ultrasonic testing. With respect to susceptibility to lamellar tearing, the evaluation method of susceptibility to lamellar testing of the Japan Society of Civil Engineers was used. As the results of our study, the following specifications were added to our model in program. Type of steel materials Grade

SM490Y

$\mathrm{Z} 25$ or equivalent (JIS G 3199)

Specification

Sulfur content of $0.008 \%$ or less

Implementation of ultrasonic testing Inspection certificate indication:SM490Y-S

\subsection{Main Girder (Steel Products)}

Type of steel materials

SM490Y

Grade

Specification

Z25 or equivalent

(JIS G 3199)

Sulfur content of

$0.008 \%$ or less

\subsection{Main construction specifications are as follows.}

Bridge type

Three-span continuous cable stayed bridge with composite box girder

Bridge length

Span length

Road specification

\author{
$1480 \mathrm{~m}$ \\ $270 m+890 m+320 m$ \\ Category 1, class 3
}


Design speed

Nu mber of lanes
$80 \mathrm{~km} / \mathrm{h}$

Two lanes for car traffic going in opposite directions (9.5

$\mathrm{m} \times 2$ ) and another two lanes

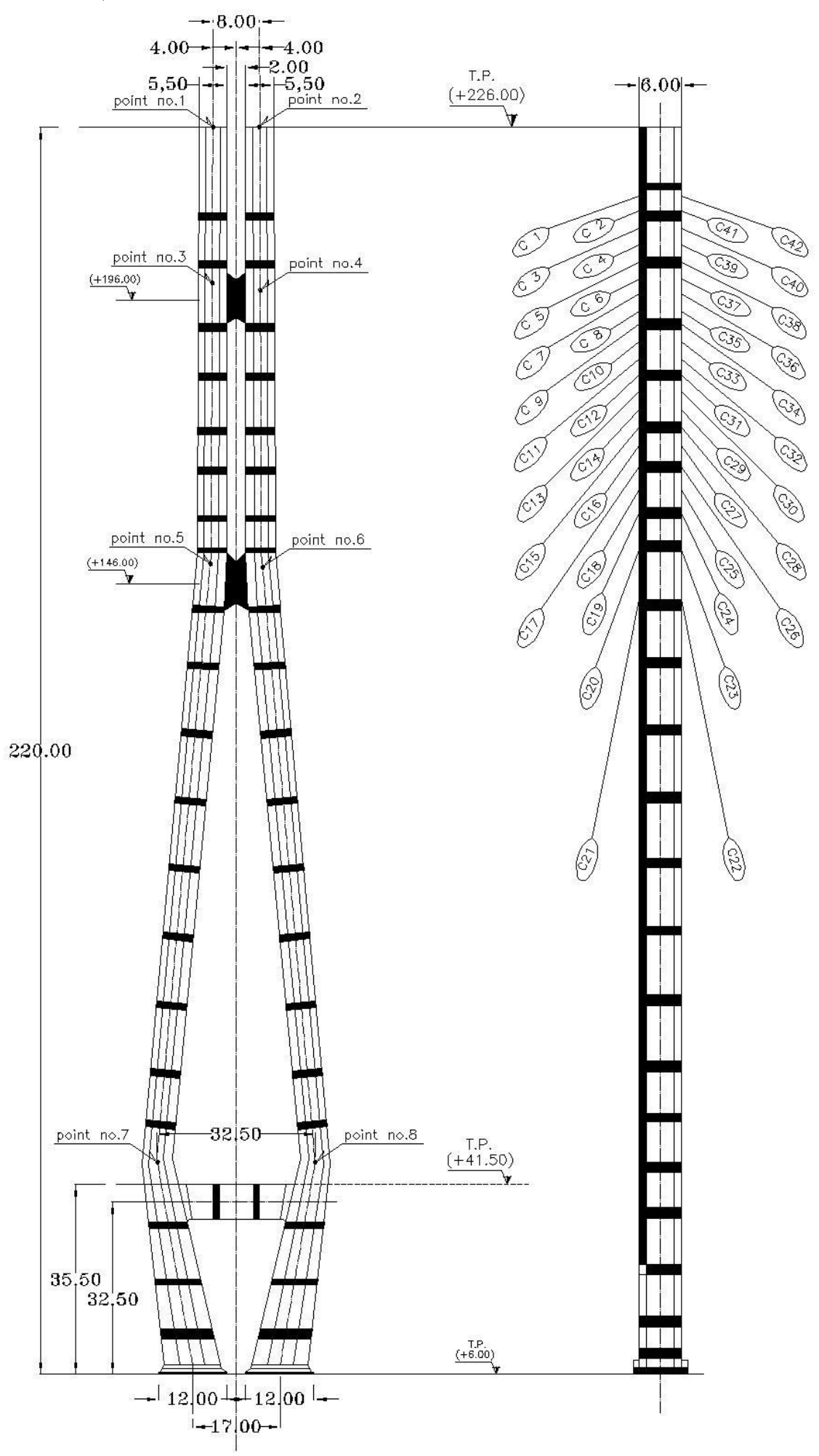

$(2.5 \mathrm{~m} \times 2)$ for motorized Bicycles, bicycles and pedestrians 


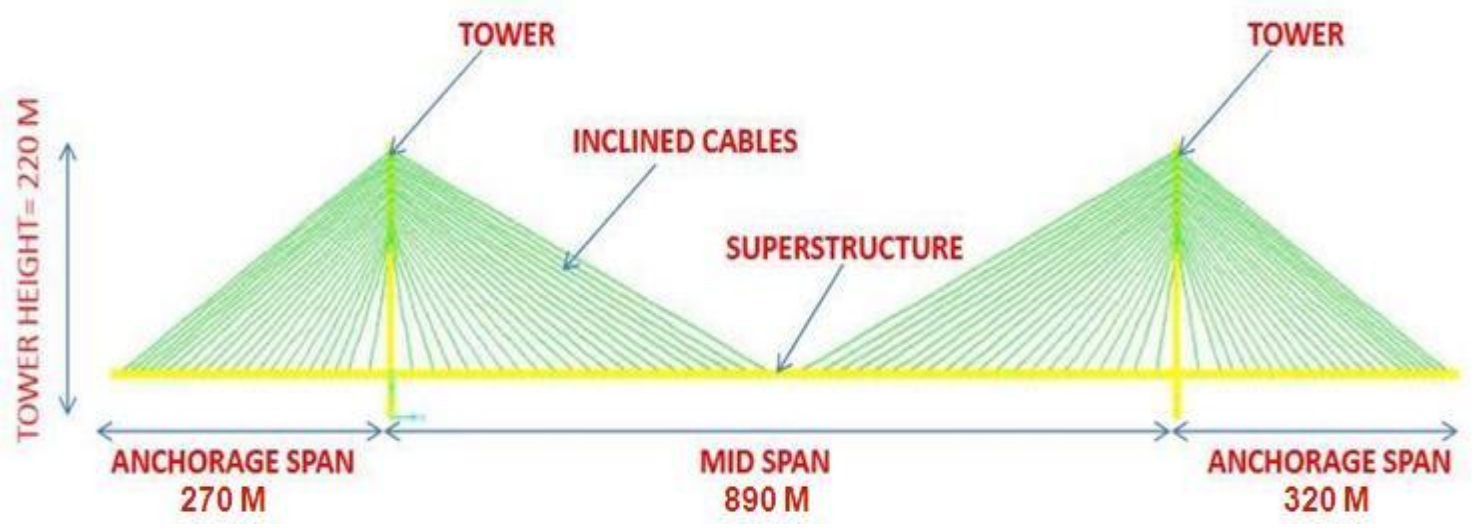

Fig. (3) nonlinear static cable stayed bridge model

Main tower

Shape Steel monocell cross section (inverted Yshaped superstructure and a base designed as a trapezoidal structure with the bottom side shorter than the topside with an extended base)

Tower height $220 \mathrm{~m}($ T.P. +226.000$)$ Sectional dimensions

$12 \mathrm{~m} \times 8.5 \mathrm{~m}$ at the base $5.561 \mathrm{~m} \times 5.881 \mathrm{~m}$ at the top

Main girder

Shape 2- main truss from two edge side with cross trusses at connection point every $5.0 \mathrm{~m}$ with steel stander cross section as stringer at the direction of motion.

Girder height

$2.7 \mathrm{~m}$ (at the center of the bridge of the standard part)

Girder width

Total width

Outside web

Cable anchoring

Pavement

$30.6 \mathrm{~m}$

interval $21.8 \mathrm{~m}$

width $23.0 \mathrm{~m}$

Asphalt pavement

\section{PROPOSED ANALYTICAL PROGRAM}

Sap program offers the widest assortment of analys is and design tools available for the structural engineer working on ordinary and special structures.

Special Frame elements will be used to descript main towers and main structure elements at deck.

\section{MODELING AND ANALYSES}

Different bracing systems will be presented which are used to decrease lateral sway of bridge deck. Tatara Bridge during construction as shown in Fig (4).

The current study will consider the stability of the bridge during the erection states at $33.3 \%, 66.6 \%$ and $100 \%$ just before combination between two sides of bridge at the erection stage as shown in Fig. (5). Finite element for model of cable stayed bridge for one Plan super structure, case (I) and in Fig. (5-a,c,d) display

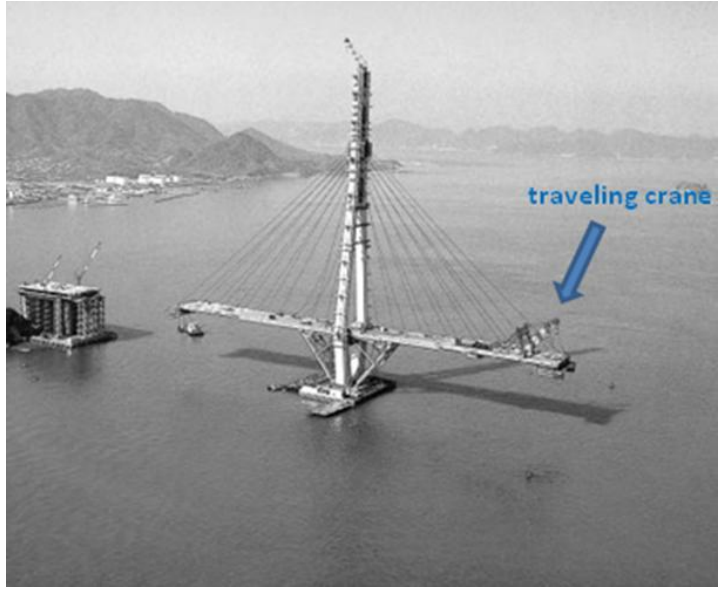

Fig. (4) The deck of Tatara bridge during erection

Finite element for model of cable stayed bridge at $33.3 \%$ at erection 7 cables are done from each side from deck and at $66.6 \%$ from erection was done 14 cables were fixed to the deck. Fig. (6) Finite element for model of cable stayed bridge for two Plan super structures case (II).

Fig. (6-a,b) displays the Finite element model of cable stayed bridge at $33.3 \%$ of the erection 7 cables were fixed from each side from deck and at $66.6 \%$ of erection was done 14 cable was done from erection.

Spacing between cables at tower is $180 \mathrm{~cm}$ and at deck spacing between cables is $15 \mathrm{~m}$ and relating between every two faced connections for cables at tower by strong horizontal beam as a diaphrag $\mathrm{m}$.

\section{GENERAL STRUCTURAL ANALYSIS}

The general structural analysis flowchart is shown in Fig. (7). To begin with, cable pre-stress was determined by infinitesimal deformation analysis to finalize the condition of the final profile. Then, sectional force analysis was conducted for each loading case by linearized finite displacement analysis using this completed system model in which initial internal force was set under this condition of the final profile. Then, sectional force, displacement and reaction were calculated and the results were edited for use in design of each me mber. 


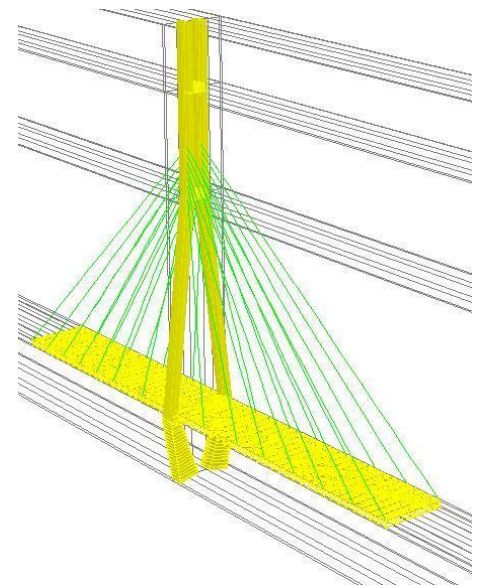

a. Finite element for model of one plane cable stayed bridge at $33.3 \%$ from erection.

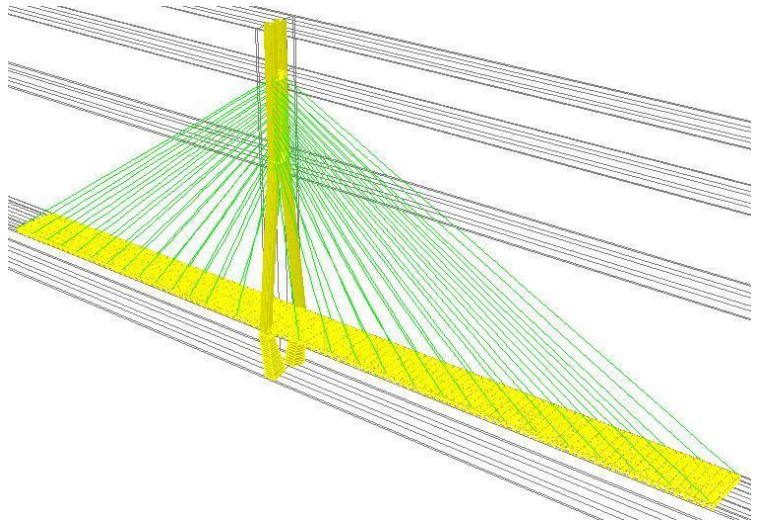

b. Finite element for model of one plane cable stayed bridge at $66.6 \%$ from erection

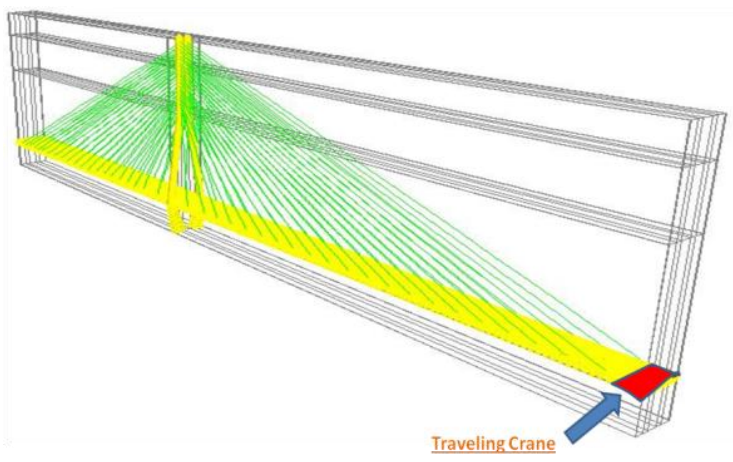

c. Finite element for model of one plane cable stayed bridge at $100 \%$ from erection just before combination between two sides of bridge

Fig. 5

\section{ANALYTICAL MODEL}

\subsection{Modeling of Main Girders}

A three-dimensional skeleton model was used for analysis of the overall structure. Fig. (8) Shows the cross section for the bridge at case (1) and case (2) of motion. In our super-structure has two main trusses from two sides and cross trusses replicated every $5 \mathrm{~m}$.



a- Finite element for model of two plane cable stayed bridge at $33.3 \%$ from erection



b- Finite element for model of two plane cable stayed bridge at $66.6 \%$ from erection

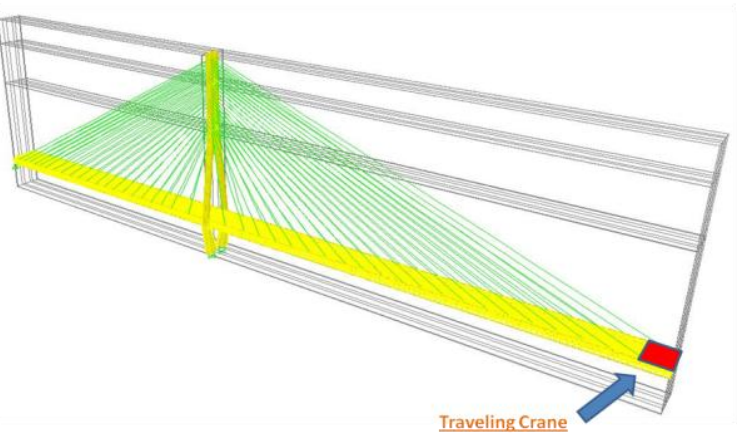

c- Finite element for model of two plane cable stayed bridge at $100 \%$ from erection just before combination between two sides of bridge

Fig. (6)
Make body between all top points for every cross truss and make a diaphrag $m$ as shell element to be decks so as to allow it to be used also as a dynamic analysis model.

\subsection{Modeling of Main Tower}

Cable length was taken into consideration for analysis of the main tower by creating a main tower model in which virtual members are extended from the 
axial center of the tower to cable anchor points (Fig. 9). In reality, even though the target points of cables for the center span and the side spans are set on the axial line of the main tower with some deviation from each other, they are sometimes designed as identical in structural analysis. In this case, it is easy, in analysis, to make bending moment of the main tower zero by balancing the horizontal components of cable tension in the final profile. But if we try to manage an actual bridge with this tension and balance horizontal components of force, bending moment will occur in the tower and can slope the tower due to misaligned setting of target points in the actual structure and the defective consequence will appear in the form of camber errors in the girder.

Table 1. Design specifications

\begin{tabular}{|c|c|c|}
\hline \multicolumn{2}{|l|}{ Bridge type } & Three-span continuous composite cable stayed bridge \\
\hline \multicolumn{2}{|c|}{ Bridge length } & $L=1480$ \\
\hline \multicolumn{2}{|l|}{ Span length } & $L=270+890+320$ \\
\hline \multicolumn{2}{|c|}{ Design live load } & $\begin{array}{l}\text { B live load (Specifications for Highway Bridges) } \\
\text { Feb. } 1994\end{array}$ \\
\hline \multicolumn{2}{|c|}{ Under clearance } & $\begin{array}{l}26 \mathrm{~m} \text { from nearly highest tide level } \\
(\text { T.P. }+2.200+26.000)\end{array}$ \\
\hline \multirow{4}{*}{ Main tower } & Shape & $\begin{array}{l}\text { Inverted Y shape with steel slits (base designed } \\
\text { as a trapezoidal structure with the bottom side } \\
\text { shorter than the topside) }\end{array}$ \\
\hline & Tower height & $H=220($ T.P. +226.000$)$ \\
\hline & \multirow[b]{2}{*}{ Sectional dimension (m) } & Base : $12^{\mathrm{IT}} \times 8.5^{\mathrm{IL}}$, Top : $6^{\mathrm{TT}} \times 6^{\mathrm{LL}}$ \\
\hline & & $\begin{array}{l}\text { (LI : direction of bridge axis; TT : direction } \\
\text { perpendicular to bridge axis) }\end{array}$ \\
\hline \multirow{3}{*}{ Main girder } & Shape & $\begin{array}{l}\text { Steel girder section: } 3 \text {-cell steel box girder } \\
\text { PC girder section: } 3 \text {-cell PC box girder }\end{array}$ \\
\hline & Girder height & $\begin{array}{l}H=2.7 \\
\text { (at the center of the bridge of the standard part) }\end{array}$ \\
\hline & Girder width & $\begin{array}{l}\text { Total width : } 30.6 \text {, Outside web interval : } 21.8 \text {, } \\
\text { Cable anchoring width : } 23.0\end{array}$ \\
\hline \multicolumn{2}{|l|}{ Cable shape } & $\begin{array}{l}\text { Two-plane multi-fan 21-level non-grout PWS } \\
\text { (strand } \phi 7 \mathrm{~mm} \text { ) }\end{array}$ \\
\hline
\end{tabular}

\section{CABLE MODELING}

A cable is converted to a rod model, with its sectional area alone being considered. The bending rigidity of the cable is ignored. Converted modulus of elasticity Eeq by the equation of H. J. Ernst, as shown below, is used to consider reduction of rigidity by the influence of cable sag.

$$
E_{e q}=\frac{E_{0}}{1+\frac{\gamma^{2} \cdot \mathrm{L}^{2} \cdot \mathrm{E}_{0}}{12 \sigma^{3}}}
$$

$\mathrm{E}_{0}$ : Modulus of elasticity of a straight cable $(2.0 \mathrm{x}$ $10^{5} \mathrm{~N} / \mathrm{mm} 2$ )

$Y:$ Unit volumetric weight of cable $=\omega / \mathrm{A}(\mathrm{N} / \mathrm{mm} 3)$

$\mathrm{L}$ : Horizontal projection length of cable $(\mathrm{mm})$

$\sigma \quad$ :Tensile stress of cable $=$ T/A $(\mathrm{N} / \mathrm{mm} 2)$

$\omega$ : Weight per unit length of cable $(\mathrm{N} / \mathrm{mm})$

$\mathrm{T}$ : Cable tension $(\mathrm{N})$

A : Cable sectional area $(\mathrm{mm} 2)$

Note that the value of $\mathrm{T}$ is the value when the final profile is prepared (when pre-stressing was studied, $\mathrm{T}$
$=(\mathrm{D}+\mathrm{PS})$ given in the basic design was used $)$. When the loading was calculated for each loading case after determination of the final profile model, cable tension $\mathrm{T}=(\mathrm{D} 2+\mathrm{PS})$ determined in the detail design phase was used to set Eeq (where D, PS, and D2 represent dead load, cable pre-stress and dead loads other than PC girder dead load).

\section{BRACING SYSTEMS FOR DECKS HAVING ONE PLAN OF MOTION.}

Many shapes of bracing systems will be investigated using finite element model having (one plan of motion) as shown in Fig. (10). Figs. (10\&11) Show different bracing systems for decks with two plans of motion.

For type (I-A \& II-A) bracing systems of all of the deck width and the total length of bridge is 2C U.P.N. NO.200 back to back.

For type (I-B \& II-B) bracing is used every 3 meters of deck width at the middle and along the total length of bridge in additional with cross bracing every 10 meters.

For type (I-C \& II-C) bracing every 3 meters of deck width at the middle and along the total length of bridge with additional crosses bracing every 20 meters is installed.

For the double plane duplicate bracing systems in upper and lower deck are used.

\section{FIXATION POINT AND CABLE SUPPORTS}

This style will be presented as the fourth system ( Type D) of bracing which using cables or weirs to support four points from deck during erection sate with four support point as a concrete blocks as shown in Fig. (12-a, b, c).

\section{EQUIVALENT STATIC EARTHQUAKE LOAD}

A response spectrum method is used to represent the earthquake load using the function 1 as shown in Fig. (13) In two directions (x-dir. And y-dir.).

Design and design checks were carried out by two seismic analytical methods: spectral response analysis, which is one of the mode analys is techniques, and time history response analysis, which is a time-domain analysis using mode analysis. Load combinations used in the design are shown by the following equation.

$D+P S+C W+E Q+L+E Q+T+S D+E$

$D$ : Dead load

$C W$ : Counterweight

$L(E Q)$ : Live load during earthquake

$S D$ : Influence of supporting point

movement

$P S$ : Pre-stres s

$E Q$ : Influence of earthquake

$T$ : Influence of temperature change

$E:$ Fabrication/erection error 
Table 2. Design loads

\begin{tabular}{|c|c|c|c|c|c|}
\hline & \multirow{2}{*}{\multicolumn{2}{|c|}{ Dead load strength (tfim/ $\mathrm{Br}$ ) }} & \multicolumn{2}{|c|}{ Completed system } & Remarks \\
\hline & & & Steel girder & PC girder & \\
\hline \multirow{9}{*}{$\begin{array}{l}\text { Bridge } \\
\text { proper }\end{array}$} & \multirow{3}{*}{\multicolumn{2}{|c|}{ Bridge proper }} & 11.01 & 63.91 & \\
\hline & & & $\sim$ & $\sim$ & \\
\hline & & & 17.05 & 92.14 & \\
\hline & \multicolumn{2}{|l|}{ Sidewalk } & 1.00 & - & PC section included in the bridge proper \\
\hline & \multicolumn{2}{|c|}{ Fairing (including inspection road) } & 1.10 & 1.10 & \\
\hline & \multicolumn{2}{|c|}{ Erection reinforcement } & 0.36 & - & \\
\hline & \multirow{3}{*}{\multicolumn{2}{|c|}{ Subtotal }} & 13.47 & 65.01 & \\
\hline & & & $\sim$ & $\sim$ & \\
\hline & & & 19.51 & 93.24 & \\
\hline \multirow{15}{*}{$\begin{array}{l}\text { Bridge } \\
\text { surface work }\end{array}$} & \multirow{4}{*}{ Pavement } & Road section & 3.13 & 3.46 & \\
\hline & & Sidewalk section & 0.43 & 0.35 & \\
\hline & & Cable anchor points & - & 0.25 & \\
\hline & & Subtotal & 3.56 & 4.06 & \\
\hline & \multirow{5}{*}{$\begin{array}{l}\text { Ground } \\
\text { covering }\end{array}$} & Median strip & - & 0.14 & \\
\hline & & Shoulder & - & 0.46 & \\
\hline & & nside of sidewalk & - & 0.16 & \\
\hline & & Outside of sidewalk & - & 0.17 & \\
\hline & & Subtotal & 0.00 & 0.93 & \\
\hline & \multirow{5}{*}{$\begin{array}{l}\text { Handrail } \\
\text { of safety } \\
\text { fence }\end{array}$} & Median strip & 0.14 & 0.11 & \\
\hline & & Shoulder & 0.24 & 0.21 & \\
\hline & & inside and outside of sidewalk & 0.18 & 0.18 & \\
\hline & & Safety fence against falling objects & 0.04 & 0.04 & \\
\hline & & Subtotal & 0.60 & 0.54 & \\
\hline & \multicolumn{2}{|c|}{ Bridge surface work - subtotal } & 4.16 & 5.53 & \\
\hline \multirow{13}{*}{ Accessories } & \multirow{6}{*}{$\begin{array}{l}\text { Management } \\
\text { facilities }\end{array}$} & Drainage device & 0.03 & - & \\
\hline & & Maintenance vehicle rail & 0.18 & - & \\
\hline & & Road lights & 0.05 & 0.05 & \\
\hline & & Fire hydrants & 0.06 & 0.06 & \\
\hline & & Electric equipment & 0.20 & 0.20 & \\
\hline & & Subtotal & 0.52 & 0.31 & \\
\hline & \multirow{3}{*}{ Utility } & Chugoku Electric Power Co. & 0.15 & 0.15 & \\
\hline & & NTT & 0.02 & 0.02 & \\
\hline & & Subtotal & 0.17 & 0.17 & \\
\hline & \multirow{3}{*}{\begin{tabular}{|l|}
\multirow{2}{*}{ Accessories } \\
\cline { 2 - 2 }
\end{tabular}} & Rail for maintenance vehicles inside girders & 0.03 & - & \\
\hline & & Cable attachments & 0.10 & - & \\
\hline & & Subtotal & 0.13 & 0.00 & \\
\hline & \multicolumn{2}{|c|}{ Accessories - subtotal } & 0.82 & 0.48 & \\
\hline \multirow{13}{*}{ Accessories } & & Drainage device & 0.03 & - & \\
\hline & & Maintenance vehicle rail & 0.18 & - & \\
\hline & Management & Road lights & 0.05 & 0.05 & \\
\hline & facilities & Fire hydrants & 0.06 & 0.06 & \\
\hline & & Electric equipment & 0.20 & 0.20 & \\
\hline & & Subtotal & 0.52 & 0.31 & \\
\hline & & Chugoku Electric Power Co. & 0.15 & 0.15 & \\
\hline & Utility & NTT & 0.02 & 0.02 & \\
\hline & & Subtotal & 0.17 & 0.17 & \\
\hline & & Rail for maintenance vehicles inside girders & 0.03 & - & \\
\hline & Accessories & Cable attachments & 0.10 & - & \\
\hline & & Subtotal & 0.13 & 0.00 & \\
\hline & Acce & essories - subtotal & 0.82 & 0.48 & \\
\hline & & & 18.45 & 71.02 & \\
\hline & & Dead loads - total & $\sim$ & $\sim$ & \\
\hline & & & 24.49 & 99.25 & \\
\hline
\end{tabular}




\begin{tabular}{|c|c|c|c|}
\hline & & \multicolumn{2}{|l|}{ Live loads } \\
\hline \multicolumn{2}{|c|}{ Vehicle live load } & \multicolumn{2}{|l|}{ B live load (Feb. 1994, Specifications for Highway Bridges) } \\
\hline \multicolumn{2}{|c|}{ Management road live load } & \multicolumn{2}{|l|}{ Superstructure design standard 2.3 .2} \\
\hline \multicolumn{2}{|c|}{ Seismic live load } & \multicolumn{2}{|c|}{$\begin{array}{l}L(E Q)=1 / 2\left[L^{*}(H)\right] \\
L^{*}(H): \mathrm{p} 2 \text { (equivalent distribution) of main load and sub load was provided to the entire bridge. }\end{array}$} \\
\hline & & \multicolumn{2}{|l|}{ Wind load } \\
\hline \multicolumn{2}{|c|}{ Applicable standard } & \multicolumn{2}{|c|}{ Onomichi-Imabani Route Wind Resistance Design Standard and its Conmentanies (fourth plan), May 1994} \\
\hline & & Seismic force & Pupose \\
\hline \multirow{5}{*}{$\begin{array}{l}\text { Input } \\
\text { waves }\end{array}$} & Short-cycle spectra & Acceleration response spectra for Tatara Bridge substructure design & For design \\
\hline & Long-cycle spectra & Design acceleration response spectra of the seismic design standard & For design \\
\hline & Long-gydk time histary wercform & Earthquake waveform for checking of superstructure of Tatara Bridge & For check \\
\hline & Vertical spectra & One half of both long-cycle and short-cycle spectra & For design \\
\hline & Hyogolen Nambou Easthquake & Seismic motion (spectra) observed at the Kobe Marine Meteorological Observatory & For check \\
\hline
\end{tabular}

Table 3. Combinations of loads






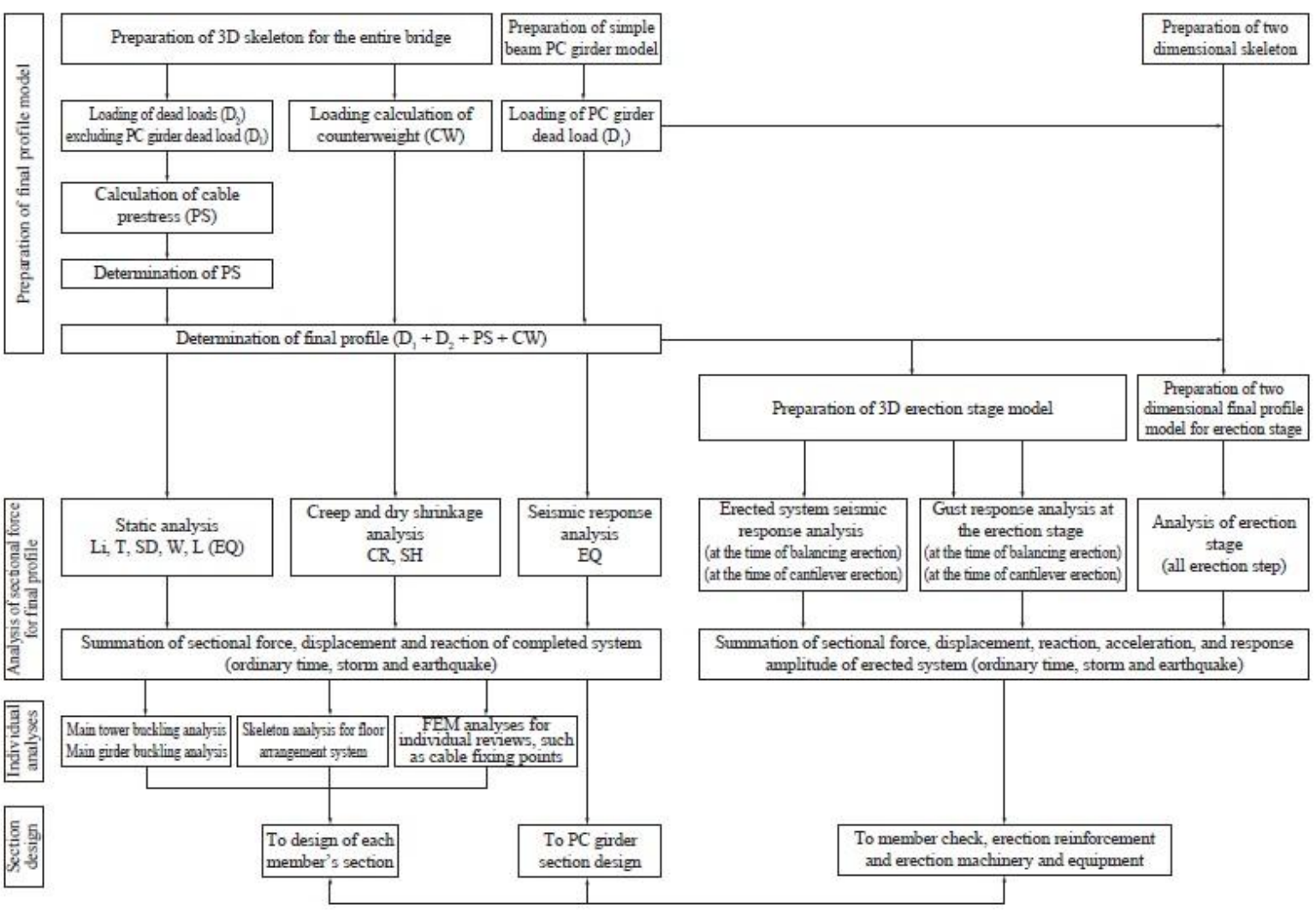

Fig. 7 Flow chart of analysis.

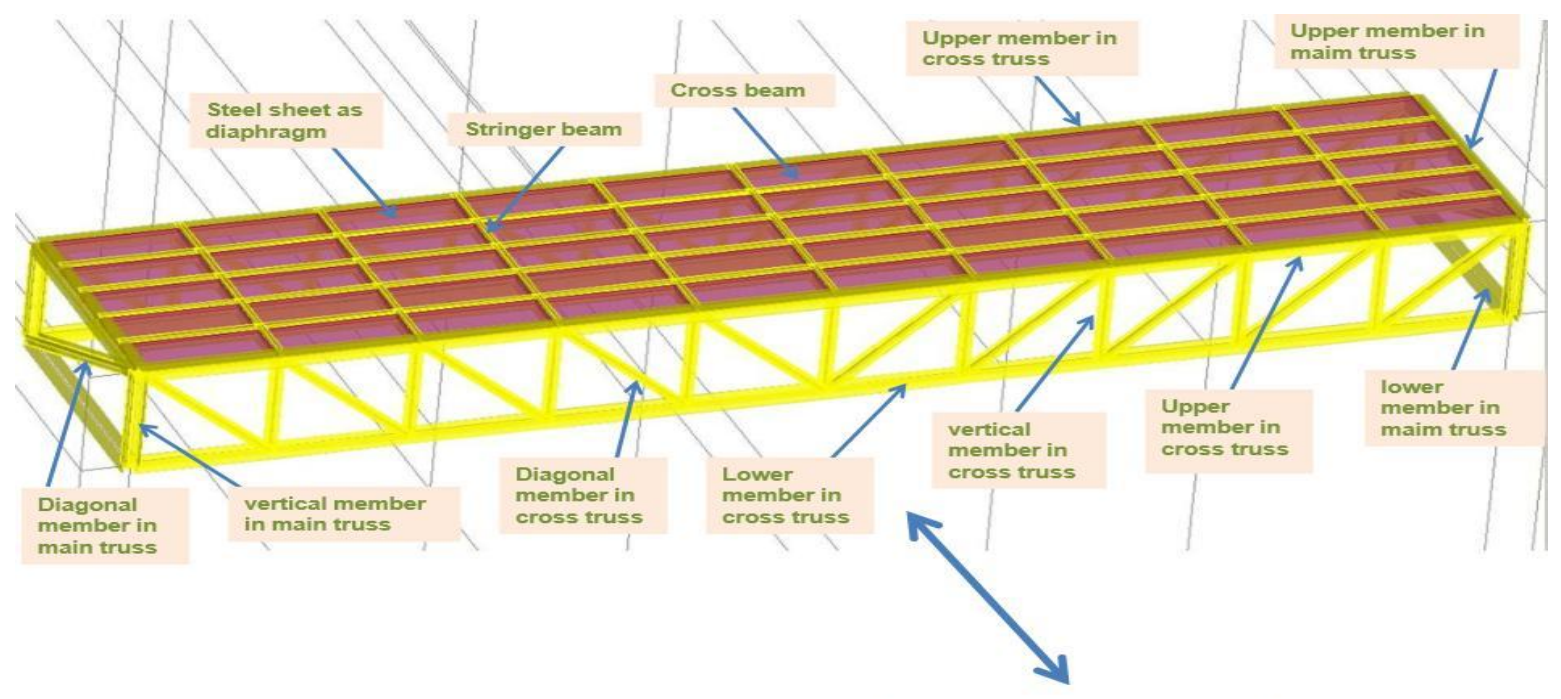

Direction of motion

a- Finite element model for The first Deck Case ( I ) 


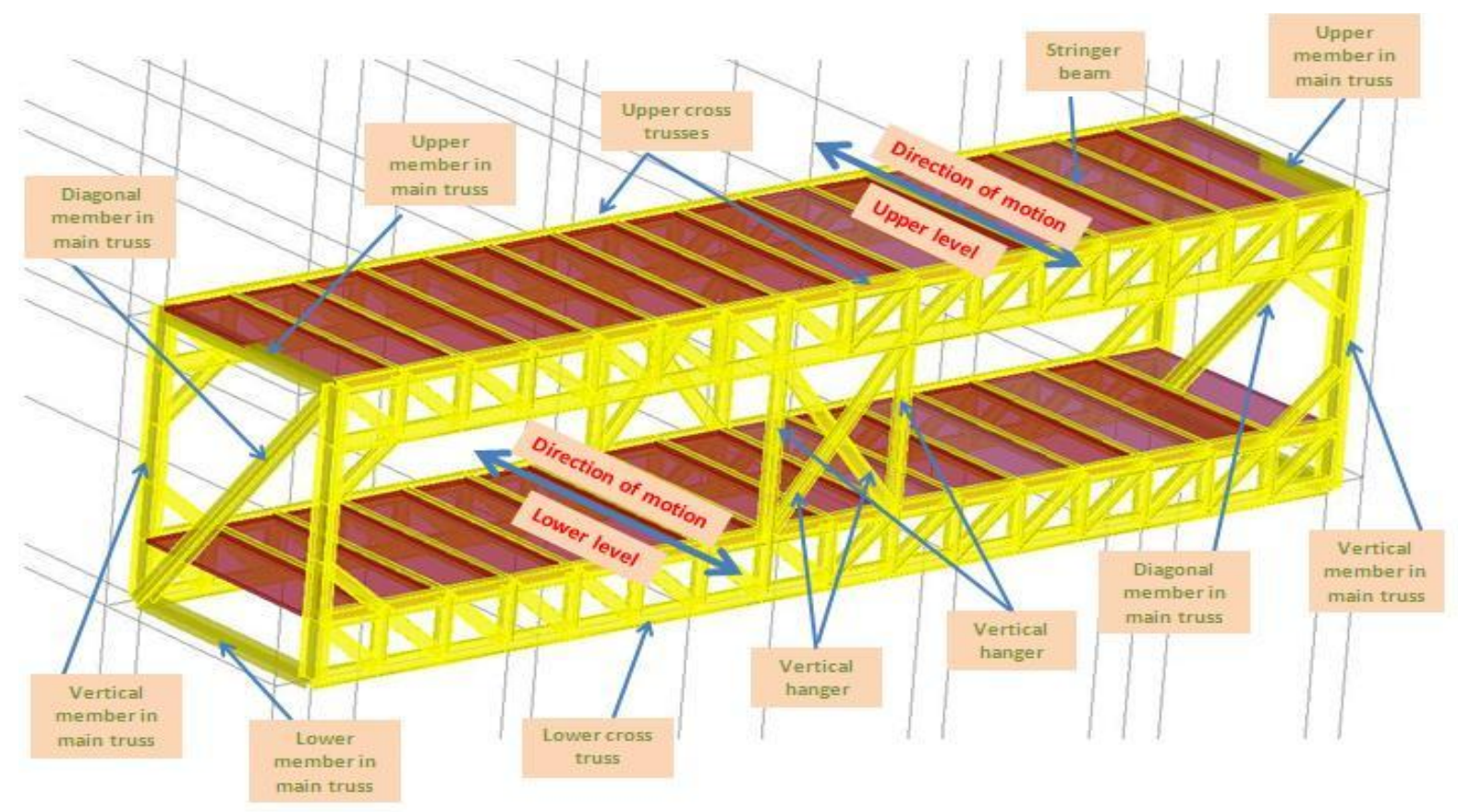

b- Finite element model for The second Deck Case (II)

Fig. 8: Main two cross sections for finite elements decks for bridges

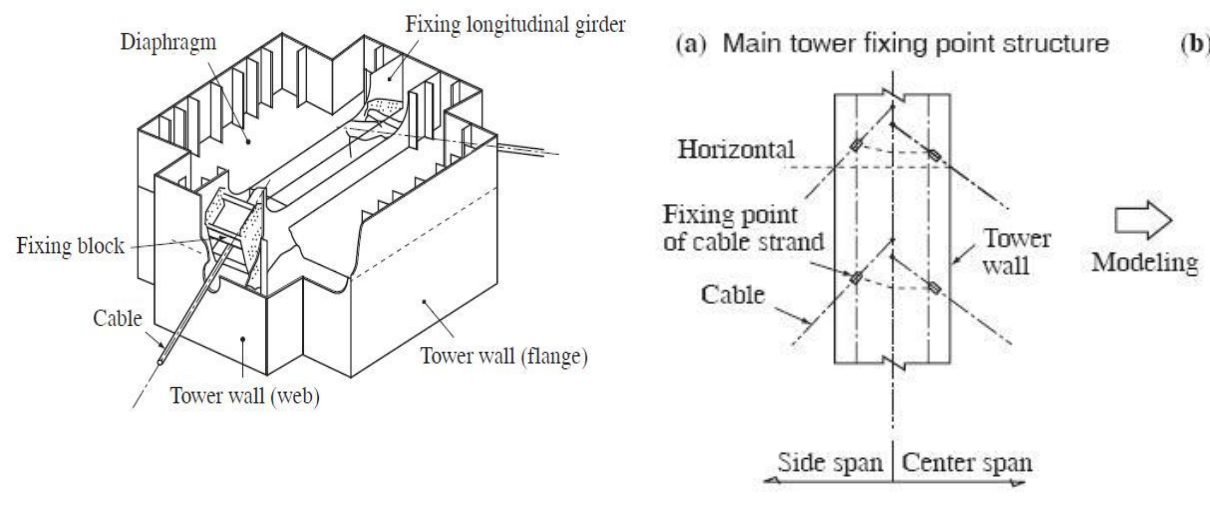

(b) Main tower fixing point model

Fig. 9: Modeling of main tower

\section{EQUIVALENT STATIC WIND LOAD}

Equivalent static wind load is applied in two directions as shown in Fig. (14).

Nonlinear analysis of Earthquake and wind loads is calculated according to Egyptian code for loads 2003.

\section{RESULTS}

Various kinds of superstructures are used these days and the designer job is to choose the suitable kind according to the particular site and the levels of motions needed (one or two) level of motions for the bridge.

First for one level of motion; tables and charts of Horizontal Drift resulted at $33 \%, 66 \%$ and $100 \%$ from erection of super-structure are shown in table (4) to table (6) and charts from (15) to chart (17).
Second; for two levels of motion; tables and charts of Horizontal Drift resulted at 33\%, 66\% and 100\% from erection of super-structure are shown in table (7) to table (9) and from chart (18) to chart (20).

From the last charts we can explain why the Bracing system type (d) (fixation points or concrete blocks) present the best geometric requirements since drifts are greatly decreased. In this system we make a fixation points a long superstructure at any points. This fixation gives the superstructure more stability to resist any forces at any direction if these loads are main loads or secondary loads.

And all these results are clear in last charts which display the big decreasing in drifts at critical points along the length of deck at all effective loads in $\mathrm{x}$ and $\mathrm{y}$ directions. 


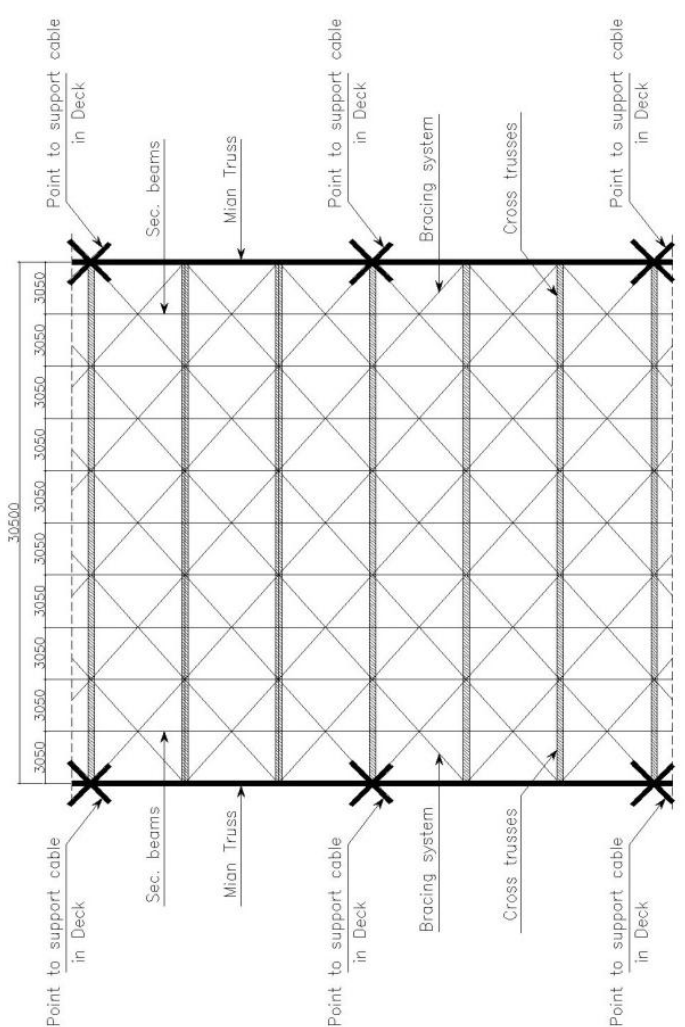

Bracing system type ( I-A)

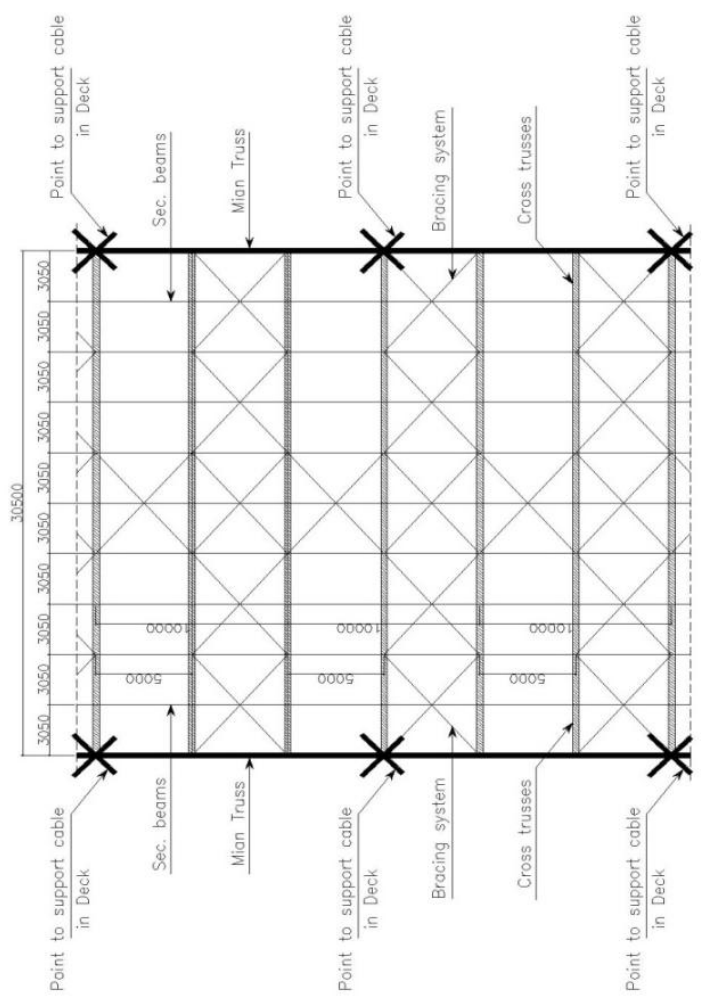

Bracing system type ( I-B )



Bracing system type ( $\mathrm{I}-\mathrm{C}$ )

Fig. (10) Bracing systems for decks having one level of motion - Case (I)

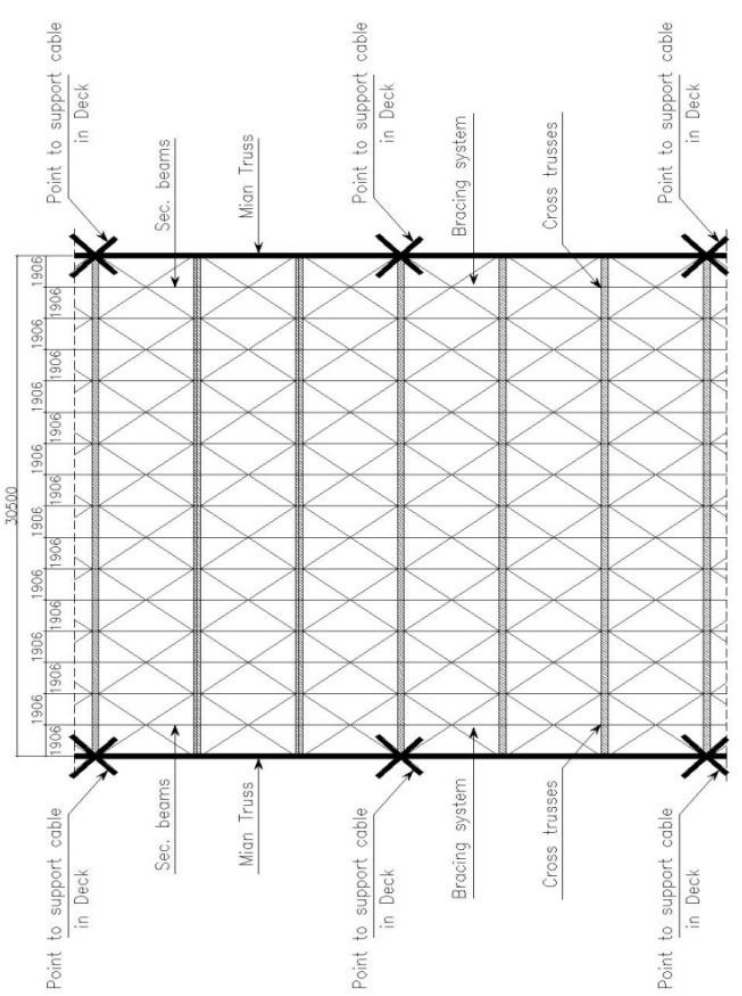

Bracing system type ( II - A ) 


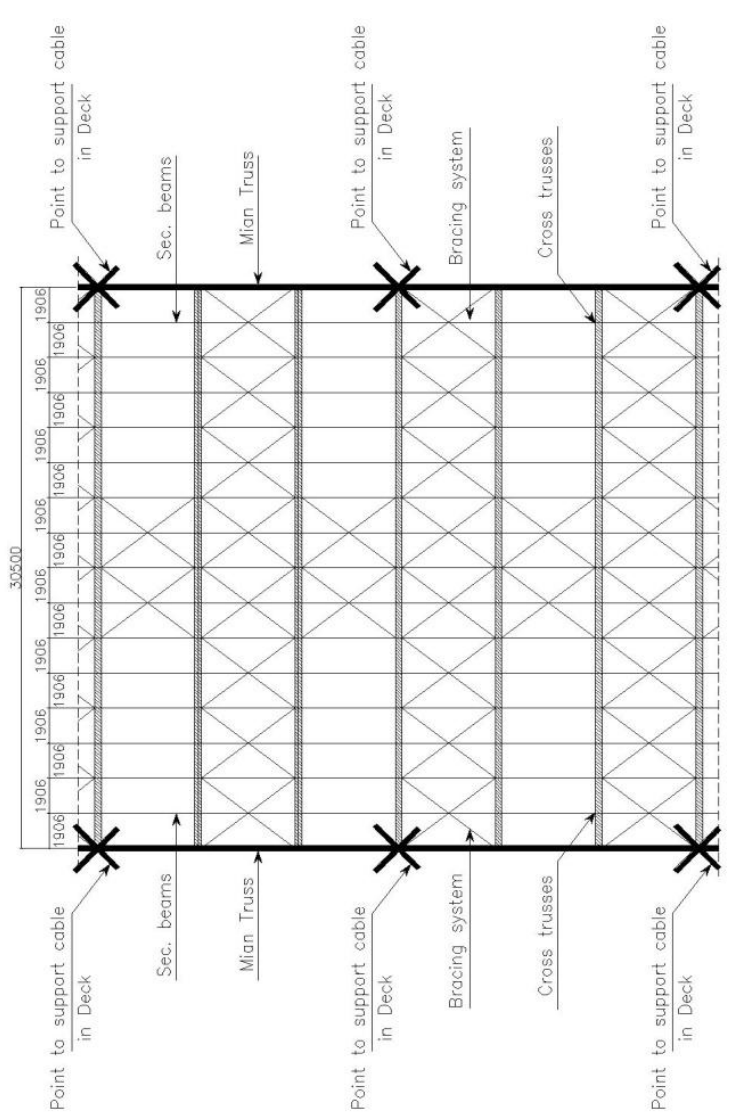

Bracing system type ( II - B )

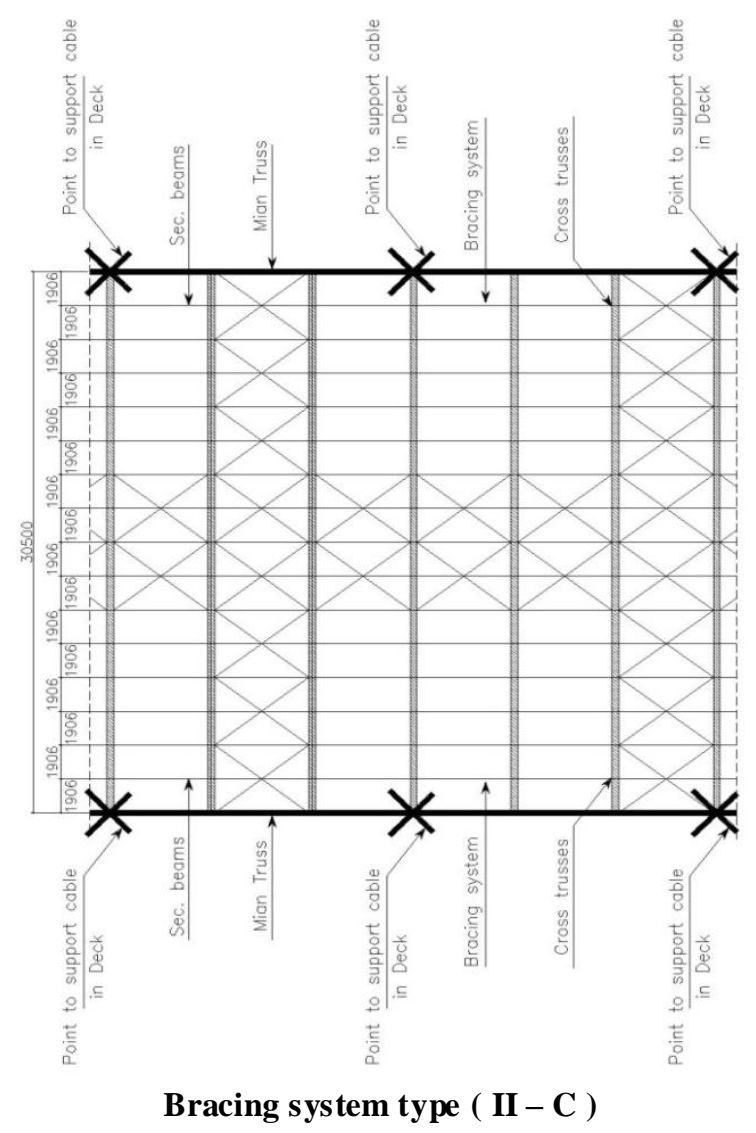

Fig. (11) Bracing systems for decks having two levels of motion - Case (II)

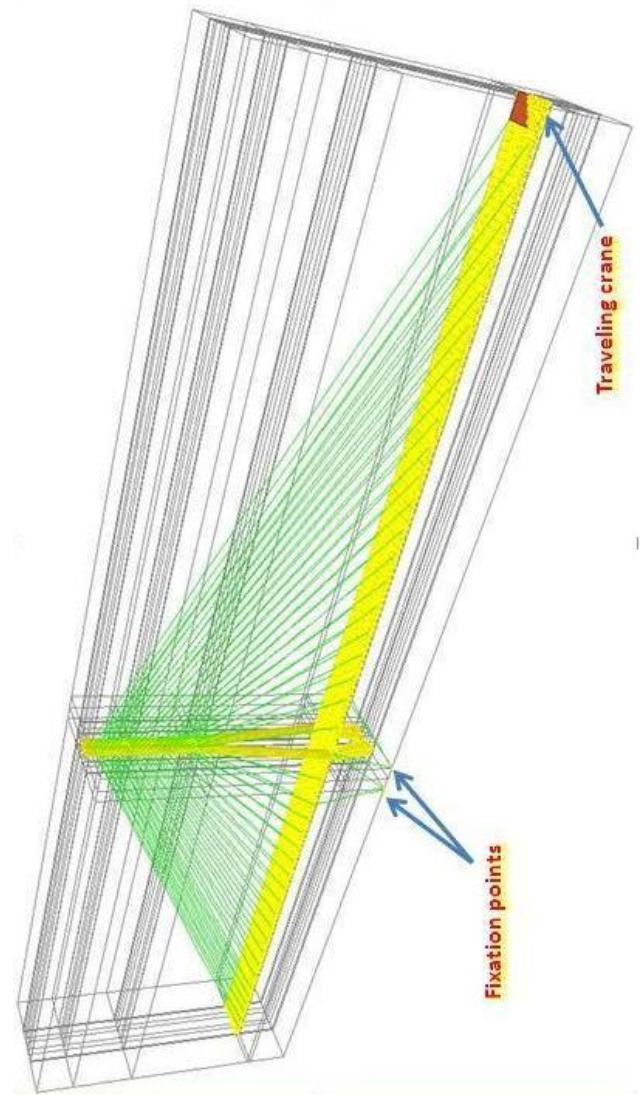

Fig. (12) Fourth system of bracing

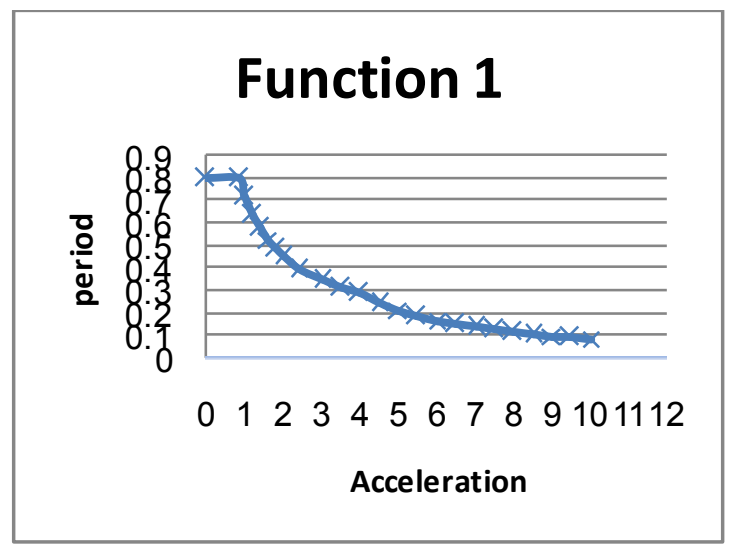

Fig. (13) Function 1 for response spectrum 


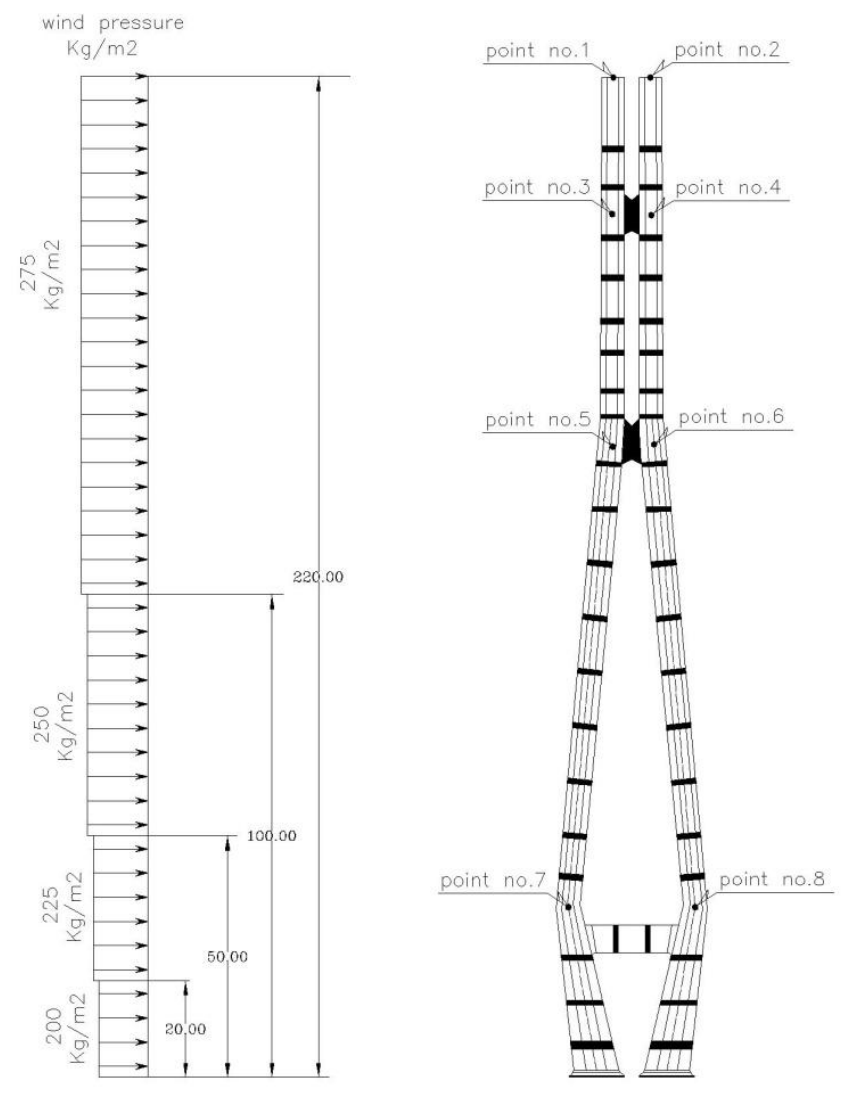

Fig. 14: Equi valent static wind pressure

\section{CONCLUSION}

Based on the experimental nonlinear finite element models in this study, the following is concluded:-

1. Min. drift due to wind load in y-dir ( $\mathrm{mm})$ at one level of motion at $33 \%$ of erection $\quad=9.47 \mathrm{~mm}$ and the current value $\quad=19.9 \mathrm{~mm}$ i.e. $\underline{\mathbf{5 2 . 4 1} \% \text { (decreasing) }}$

2. Min. drift due to wind load in $y$-dir $(\mathrm{mm})$ at one level of motion at $66 \%$ from erection $=143.07 \mathrm{~mm}$ And the current value $\quad=219.27 \mathrm{~mm}$ i.e. $\mathbf{3 4 . 7 5 \% \text { (decreasing) }}$

3. Min. drift due to wind load in y-dir ( $\mathrm{mm})$ at one level of motion at $100 \%$ fro $m$ erection $=1335.84$ $\mathrm{mm}$ and the current value $\quad=1689.82 \mathrm{~mm}$ i.e. $20.95 \%$ (decreasing)

4. Min. drift due to wind load in $\mathrm{x}-\mathrm{d}$ ir $(\mathrm{mm})$ at two level of motion at $33 \%$ from erection $=27.9 \mathrm{~mm}$ and the current value i.e. $10.83 \%$ (decreasing)

5. Min. drift due to wind load in $x-d$ ir $(\mathrm{mm})$ at two level of motion at $66 \%$ fro $\mathrm{m}$ erection $=219.26 \mathrm{~mm}$ and the current value $=322.71 \mathrm{~mm}$ i.e. $\underline{\mathbf{3 2 . 0 6} \% \text { (decreasing) }}$

6. Min. drift due to wind load in $\mathrm{x}$-dir ( $\mathrm{mm})$ at two level of motion at $100 \%$ from erection $=2559.81$ $\mathrm{mm}$ and the current value $=3245.74 \mathrm{~mm}$
7. Min. drift due to earth-quack load in y-dir $(\mathrm{mm})$ at one level of motion at $33 \%$ of erection $=9.16 \mathrm{~mm}$ and the current value $\quad=24.6 \mathrm{~mm}$ i.e. $62.76 \%$ (decreasing)

8. Min. drift due to earth-quack load in y-dir ( $\mathrm{mm})$ at one level of motion at $66 \%$ of erection $=173 \mathrm{~mm}$ and the current value $=199.7 \mathrm{~mm}$ i.e. $13.37 \%$ (decreasing)

9. Min. drift due to earth-quack load in y-dir ( $\mathrm{mm})$ at one level of motion at $100 \%$ of erection $=464.8$ $\mathrm{mm}$

and the current value $\quad=574.55 \mathrm{~mm}$

$$
\text { i.e. } 19.10 \% \text { (decreasing) }
$$

10. Min. drift due to earth-quack load in $\mathrm{x}$-dir $(\mathrm{mm})$ at two level of motion at $33 \%$ of erection $=23.53$ $\mathrm{mm}$

and the current value $\quad=28.14 \mathrm{~mm}$ i.e. $16.38 \%$ (decreasing)

11. Min. drift due to earth-quack load in $\mathrm{x}$-dir ( $\mathrm{mm})$ at two level of motion at $66 \%$ of erection = $173.48 \mathrm{~mm}$ and the current value $\quad=200.12 \mathrm{~mm}$ i.e. $13.31 \%$ (decreasing)

12. Min. drift due to earth-quack load in $\mathrm{x}$-dir $(\mathrm{mm})$ at two level of motion at $100 \%$ of erection $=355.62$ $\mathrm{mm}$

and the current value $\quad=406.99 \mathrm{~mm}$

i.e. $12.62 \%$ (decreasing)

\section{REFERENCES}

[1] Yabuno Masashi and others, Design of tatara Bridge, Technical Report Vol. 36 No. 2 June 2008

[2] Satouy Yoshiyuki and others, Erection of Tatara Bridge, Technical Report Vol. 36 No. 2 June 2008

[3] M. S. TROITSKY, D.Sc. cable stayed bridges 1988.

[4] Noguchi et al., 2003; Sato et al., 2003; and Petrangeli et al., 2000, Construction of Nagisa Bridge Hybrid System of Cable, 30th Conference on our world in concrete \& structurs: 23-24 august 2005, Singapore

[5] George Moir et al, 2010, Construction Engineering of Phu My Cable-Stayed Bridge, Vietnam, Construction Engineering Phu My Bridge - Edmonds.

[6] Chen Bo and Morgenthal et al., 2011, Health monitoring and vibration control of steel space structures, Hong Kong Polytechnic University (Hong Kong), 2007 - Space frame structures

[7] Walter Podolny JR. and John B.scalzi, construction and design of cable stayed bridges 1986 . 
[8] ECP Egyptian code of practice for steel construction and bridges (allowable stress design) code no. 205-2001 edition-2009.

[9] Negrao and Simoes, Optimization of cable stayed bridges with three dimensional mode ling 1997.

[10] Karoumi, modeling of cable-stayed bridges for analysis of traffic induced 2000.

[11] George Mori, Construction Engineering of Phu My Cable-Stayed Bridge, Vietnam 2010.

[12] Han Dajian and SU Cheng, construction control of the yamen cable stayed bridge 2003.
[13] Guido Moregenthal; Robin Sham; and Brian West Engineering the Tower and Main Span Construction of Stonecutters Bridge 2009

[14] AISC code of standard practice for steel buildings and bridges 2000 .

[15] ASCE standard American Society of Civil Engineers Minimum Design Loads for Buildings and Other Structures.

[16] T. Fujiwara and A. Moriyama, Wind-Proof Design on the Tower of Tatara Bridge, Honshi. Technical Report Vol.19 No.74 Apr. 1995 
Case (I)

\begin{tabular}{|l|c|c|}
\hline \multicolumn{1}{|c|}{ Table (4) Max. Herizontal Drift at 33\% from erection (mm) } \\
\hline Bracing type & $\begin{array}{c}\text { Drift due to wind } \\
\text { force }\end{array}$ & $\begin{array}{c}\text { Drift due to earth } \\
\text { quack force }\end{array}$ \\
\hline 1- Without bracing & 19.9 & 24.6 \\
\hline 2- Bracing Type (a) & 18.7 & 24.74 \\
\hline 3- Bracing Type (b) & 18.72 & 24.66 \\
\hline 4- Bracing Type (e) & 18.73 & 24.63 \\
\hline $\begin{array}{l}\text { 5- Bracing Type (d) } \\
\text { Concrete blocks }\end{array}$ & 9.47 & 9.16 \\
\hline
\end{tabular}

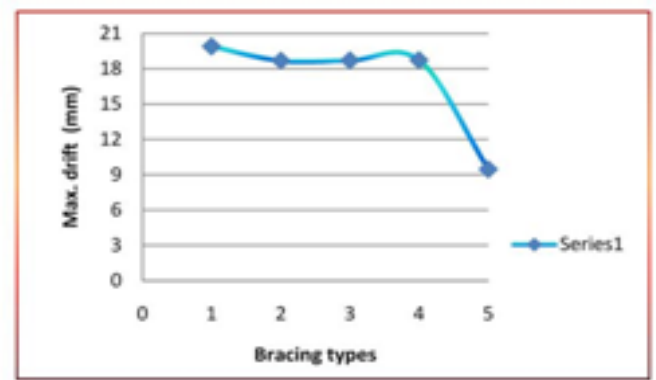

Fig. (15-a) Herizontal drift at $33 \%$ from erection due to wind loas

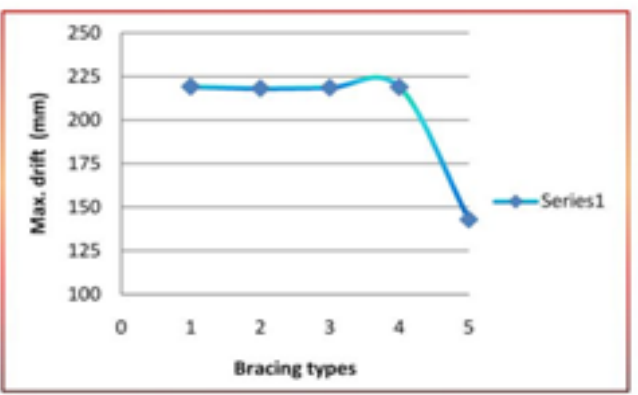

Fig. (16-a) Herizontal drift at $66 \%$ from erection due to nind load

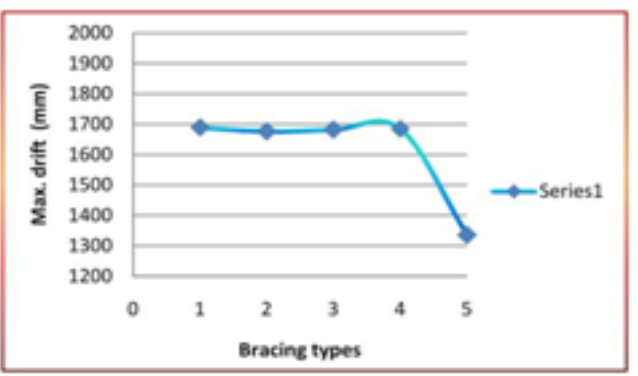
Fig. (17-a) Herizoatal drift at $100 \%$ from
erection due to wied load

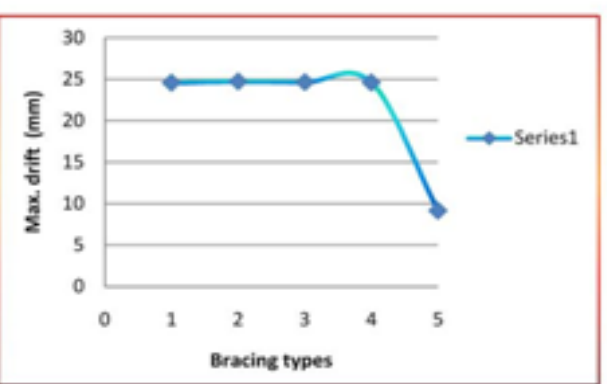

Fig. (15-b) Horixostal drift at $33 \%$ from crection due to earth quack force

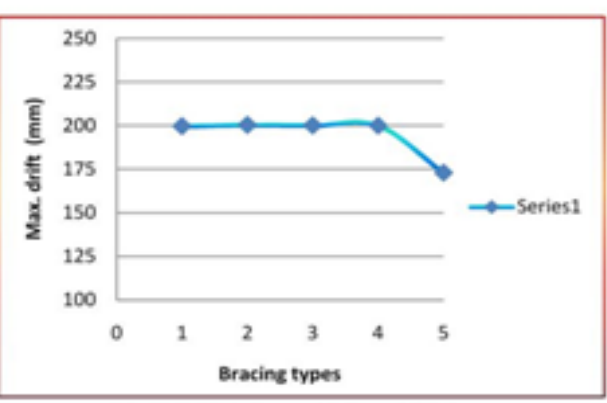

Fiz. (16-b) Horixontal drift at $66 \%$ from erection due to earth quack force

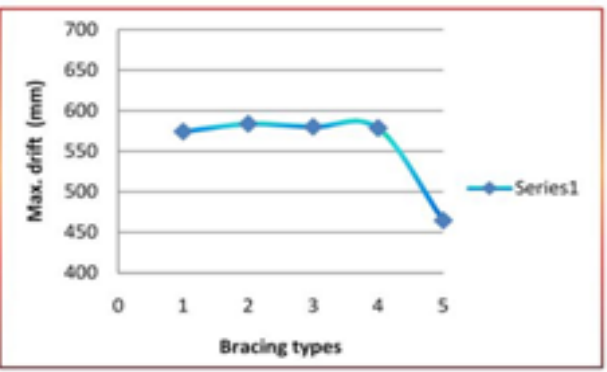

Fig. (17-b) Herizontal drift at 100\% from erection due to earth ouack force 
Case (II)

\begin{tabular}{|l|c|c|}
\hline \multicolumn{2}{|c|}{ Table (7) Max. Horizontal Drift at 33\% from erection (mm) } \\
\hline \multicolumn{1}{|c|}{ Bracing type } & $\begin{array}{c}\text { Drift due to wind } \\
\text { force }\end{array}$ & $\begin{array}{c}\text { Drift due to earth } \\
\text { quack force }\end{array}$ \\
\hline 1- Without bracing & 31.29 & 28.14 \\
\hline 2- Bracing Type (a) & 30.84 & 25.87 \\
\hline 3- Bracing Type (b) & 31.08 & 26.29 \\
\hline 4- Bracing Type (c) & 31.17 & 27.23 \\
\hline 5- Bracing Type (d) & 27.9 & 23.53 \\
\hline \\
Concrete blocks
\end{tabular}

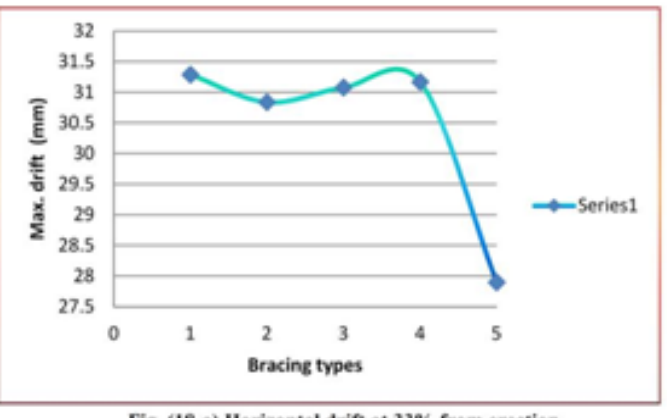

Fig. (18-a) Herizontal drift at $33 \%$ from erection due to wind load

\begin{tabular}{|l|c||c|}
\hline \multicolumn{3}{|c|}{ Table (8) Max. Horizontal Drift at 66\% from erection (mm) } \\
\hline \multicolumn{1}{|c|}{ Bracing type } & $\begin{array}{c}\text { Drift due to wind } \\
\text { force }\end{array}$ & $\begin{array}{c}\text { Drift due to earth } \\
\text { quack force }\end{array}$ \\
\hline 1- Without bracing & 322.71 & 200.12 \\
\hline 2- Bracing Type (a) & 312.94 & 201.42 \\
\hline 3- Bracing Type (b) & 316.93 & 201.2 \\
\hline 4- Bracing Type (e) & 317.33 & 201.24 \\
\hline 5- Bracing Type (d) & 219.26 & 173.48 \\
\hline Concrete blocks & & \\
\hline
\end{tabular}



Fig. (19-a) Horizental drift at $66 \%$ from erection due to$$
\text { wind load }
$$

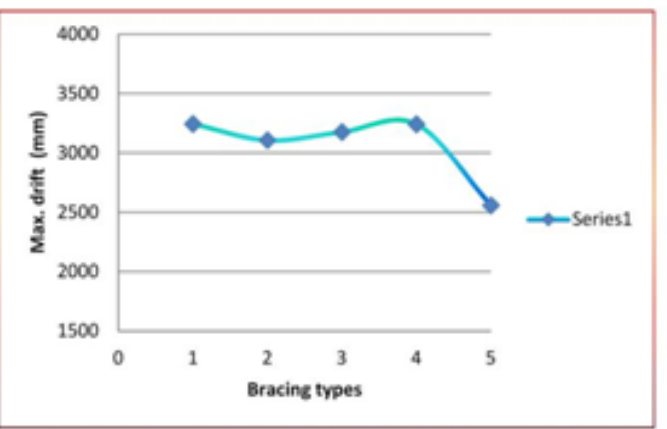

Fig. (20-a) Horizontal drift at 100\% from erection due to

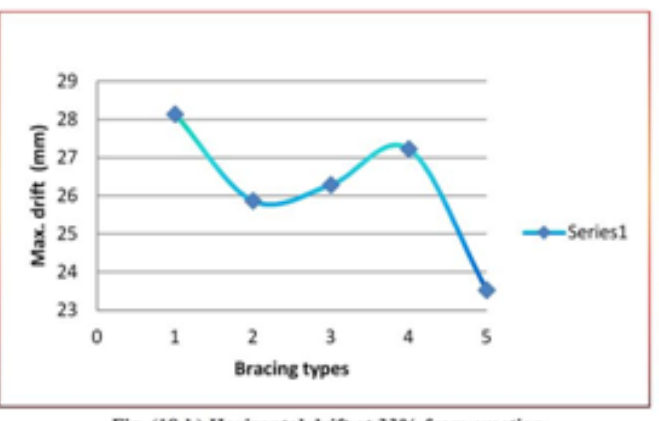

Fig. (18-b) Horizontal drift at $33 \%$ from erection due to earth auack force



Fig. (19-b) Horizontal drift at $66 \%$ from ereetion due to earth quack force

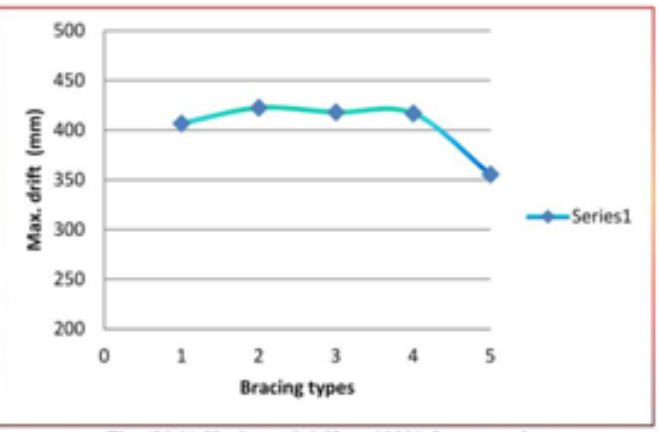

Fig. (20-b) Horizontal drift at 100\% from erection 